\title{
RANCANG BANGUN SISTEM PENGUKURAN KECEPATAN PUTAR GENERATOR PADA TURBIN ANGIN MENGGUNAKAN OPTOCOUPLER BERBASIS MIKROKONTROLER ATMEGA8535
}

\author{
Rifdian I.S ${ }^{1}$, Hartono ${ }^{2}$ \\ 1),2) Politeknik Penerbangan Surabaya \\ Jl. Jemur Andayani I, No. 73 Surabaya 60236 \\ Email : rifdian.anto@gmail.com
}

\begin{abstract}
ABSTRAK
Kecepatan angin dan desain sudu mempengaruhi besarnya kecepatan putaran generator, sehingga data kecepatan putar sudu dan kecepatan putar generator menjadi salah satu acuan untuk berbagai keperluan seperti mendesain sudu turbin, data pembanding dengan output generator dalam menentukan kinerja generator dan sistem keamanan turbin. Tujuan dari penelitian ini adalah merancang alat pengukur kecepatan putar (rpm) generator yang dihasillkan dari pergerakan turbin angin. Prinsip kerja dari alat ini yaitu menembakkan cahaya infra merah pada bidang reflektif yang akan memantulkan cahaya inframerah yang kemudian diterima oleh detektor. Alat pengukur kecepatan putar ini menggunakan sensor led inframerah yang dapat memancarkan cahaya inframerah yang tidak kasat mata. Cahaya inframerah merupakan gelombang cahaya yang berada pada spektrum cahaya tak kasat mata yang ditembakkan ke daerah reflektif kemudian ditangkap oleh phototransistor sebagai receiver. Output receiver akan dikonversi dalam bentuk kecepatan putar (rpm) oleh mikrokontroler. Nilai rpm akan ditampilkan melalui display lcd. Berdasarkan hasil pengujian alat diperoleh bahwa error pengukuran paling kecil pada kecepatan 6000 RPM dengan prosentase error sebesar $0.00 \%$, sedangkan prosentase error terbesar pada kecepatan 500 RPM sebesar $0.04 \%$. Dari data hasil pengujian yang telah dilakukan, hasil pengukuran masih dalam batas toleransi yaitu sebesar $\pm 10 \%$.
\end{abstract}

Kata Kunci : kecepatan putar, inframerah, generator, phototransistor, mikrontroler

\section{PENDAHULUAN}

Perkembangan teknologi yang pesat mendorong penggunaan energi dalam jumlah yang besar. Hal ini mengakibatkan semakin menipisnya cadangan bahan bakar fosil sebagai sumber energi utama. Banyak sekali penelitian yang telah mencari sumber energi alternatif, khususnya energi listrik. Untuk itu diperlukan energi alternatif sebagai penghasil energi listrik yang terbarukan seperti sinar matahari, tenaga air dan angin. Sumber energi terbarukan adalah sumber energi ramah lingkungan yang tidak mencemari lingkungan dan tidak memberikan kontribusi terhadap perubahan iklim dan pemanasan global seperti pada sumbersumber tradisional lain. Inilah alasan utama dimana energi terbarukan sangat terkait dengan masalah lingkungan dan kehidupan banyak orang

Banyak orang menunjuk energi terbarukan sebagai antesis untuk bahan bakar fosil. Pemanfaatan tenaga air dan angin ini salah satu yang sedang popular dilakukan. Banyak sekali orang membuat kincir angin dan kincir air untuk di rubah menjadi energi listrik. Kedua jenis kincir ini pasti membutuhkan generator untuk merubah energi mekanis menjadi energi listrik yang disebut generator. Generator yang tersedia biasanya berjenis high speed induction generator. Generator jenis ini membutuhkan putaran tinggi dan membutuhkan energi listrik awal untuk membuat medan magnetnya. Sedangkan pada penggunaan kincir angin di butuhkan generator yang berjenis low speed dan tanpa energi listrik awal, karena biasanya di 
tempatkan di daerah-daerah yang tidak memiliki aliran listrik. Pada penelitian kali ini akan menggunakan generator low speed yang akan di aplikasikan dengan turbin angin.

Turbin angin adalah alat yang digunakan untuk merubah energi angin (kinetik) menjadi energi listrik. Dalam menghasilkan listrik, turbin angin dipengaruhi oleh kecepatan angin, desain sudu, dan kinerja generator. Kecepatan angin dan desain sudu mempengaruhi besarnya kecepatan putaran generator sehingga data kecepatan putar generator dan turbin menjadi salah satu acuan untuk berbagai keperluan seperti mendesain turbin, data pembanding dengan output generator dalam menentukan kinerja generator dan sistem keamanan turbin.

Permasalahan yang terjadi pada turbin angin adalah tidak adanya data kecepatan putar sudu turbin dan generator. Oleh karena itu, diperlukan suatu sistem pengukuran yang dapat menunjukkan data tersebut setiap waktunya dan memberikan kondisi terkini dari putaran sudu turbin angin dan generator. Sistem pembangkit listrik tenaga angin dapat digambarkan seperti gambar 1.

Pengukur kecepatan putar adalah suatu alat ukur yang dibuat dan didesain untuk mengukur kecepatan objek yang berputar. Objek yang akan diukur dalam penelitian ini adalah banyaknya putaran permenit (rpm) dari porors generator. Cara kerja dari alat ini, yaitu menembakkan cahaya infra merah pada bidang reflektif yang akan memantulkan cahaya infra merah dan diterima oleh detektor. Cahaya yang diterima oleh detektor akan diproses oleh mikrokontroller dan ditampilkan pada display liquid crystall display.

\section{METODE PENELITIAN}

\section{Diagram Blok Sistem}

Secara umum diagram dari alat pengukur kecepatan putar generator adalah seperti pada gambar 1.

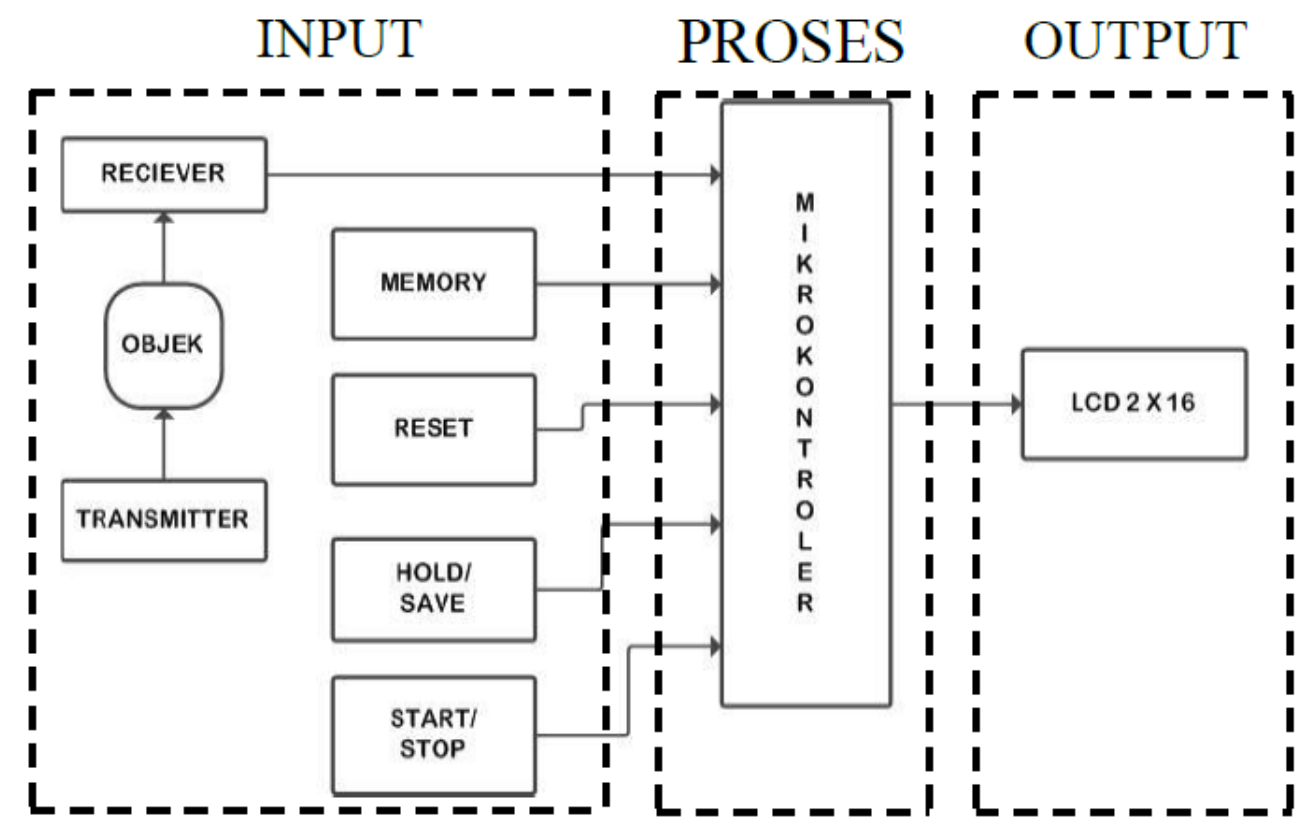

Gambar 1. Diagram Blok Sistem

Transmitter Inframerah memancarkan gelombang yang ditembakkan ke objek. Pada objek diberi garis putih sebagai bidang reflektif kemudian akan ditangkap oleh phototransistor sebagai receiver. Output receiver akan dikonversi dalam bentuk rpm oleh mikrokontroller. Nilai rpm akan ditampilkan melalui display LCD 16x2. Apabila nilai yang ditunjukan display mulai stabil dapat ditekan HOLD/SAVE. Display akan otomatis berhenti kemudian program akan menampilkan dan menyimpan nilai data pengukuran. Transmitter dan receiver dipasang pada poros generator berserta bidang reflektifnya. 


\section{Diagram Alir/Flowchart Program}

Proses /alur pemrograman dari pengukur kecepatan putar generator ini dapat ditunnjukkan pada gambar 2.

Pada flow chart gambar 2, inisialisasi Timer/Counter berfungsi untuk mengolah frekuensi dari output rangkaian modul sensor $D 80 N K$. Frekuensi akan ditampilkan pada display $L C D 16 \times 2$ dalam satuan rpm. Saat data yang ditampilkan mulai stabil, tekan Hold/Save. Display otomatis berhenti, kemudian program akan menampilkan dan menyimpan nilai data pengukuran. Apabila tombol Hold/Save tidak ditekan maka proses counting akan terus berjalan. Saat proses pengambilan data telah selesai, tekan tombol Memory untuk menampilkan data yang telah disimpan.

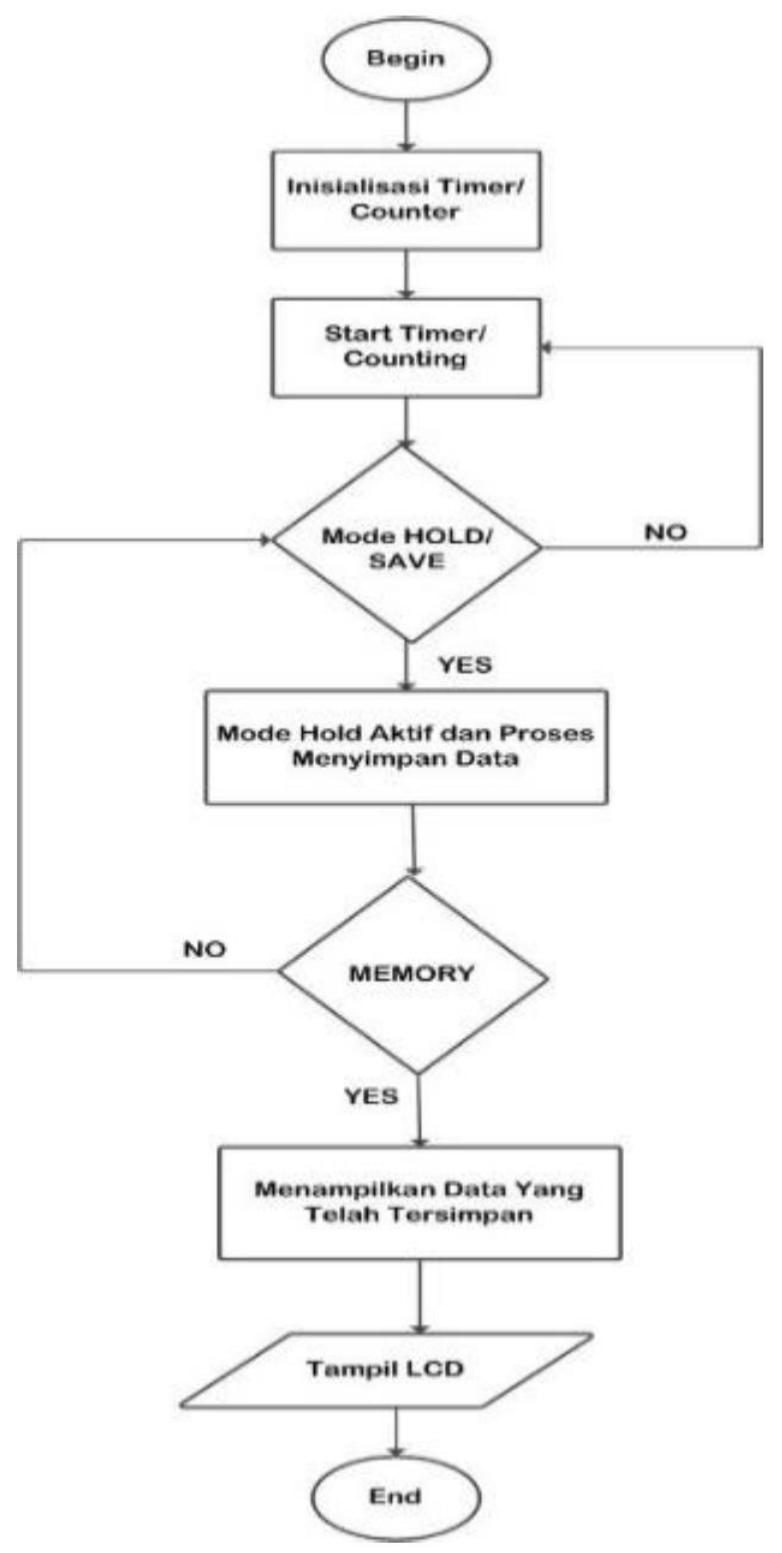

Gambar 2. Flow chart program 


\section{HASIL PENGUJIAN dan ANALISA}

\section{Hasil Pengukuran Test Point}

1. Hasil Pengukuran dengan Oscilocope dari Output Sensor untuk kecepatan $1000 \mathrm{rpm}$

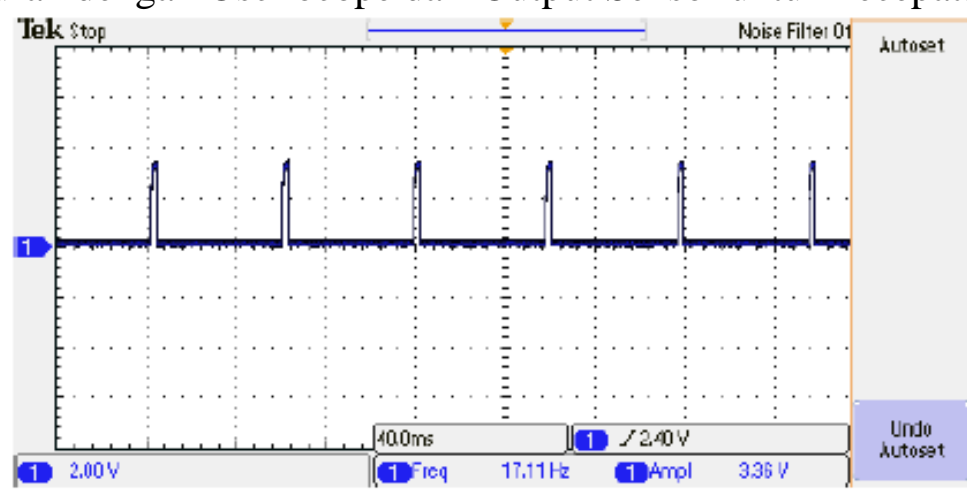

Gambar 3. Output sensor untuk kecepatan 1000 rpm

2. Hasil Pengukuran dengan Oscilocope dari Output Sensor untuk kecepatan 2000 rpm

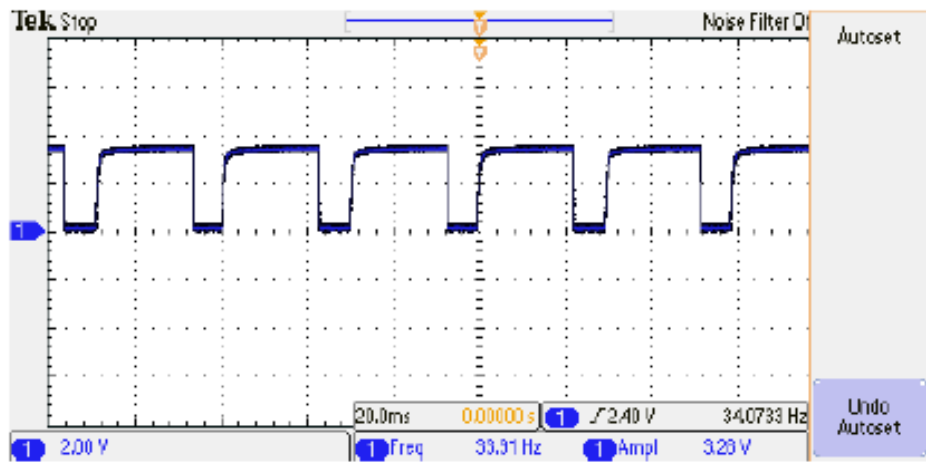

Gambar 4. Output sensor untuk kecepatan 2000 rpm

3. Hasil Pengukuran dengan Oscilocope dari Output Sensor untuk kecepatan $4000 \mathrm{rpm}$

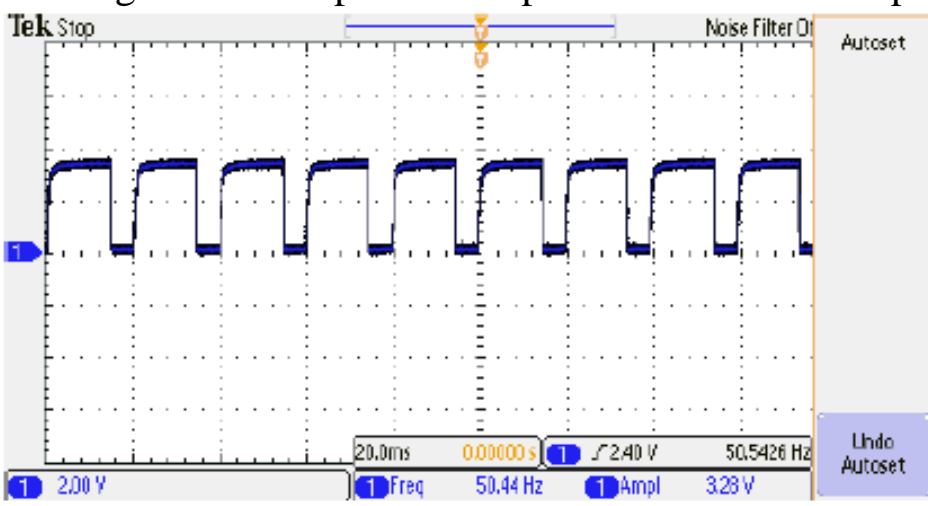

Gambar 5. Output sensor untuk kecepatan 4000 rpm 
4. Hasil Pengukuran dengan Oscilocope dari Output Sensor untuk kecepatan $5000 \mathrm{rpm}$

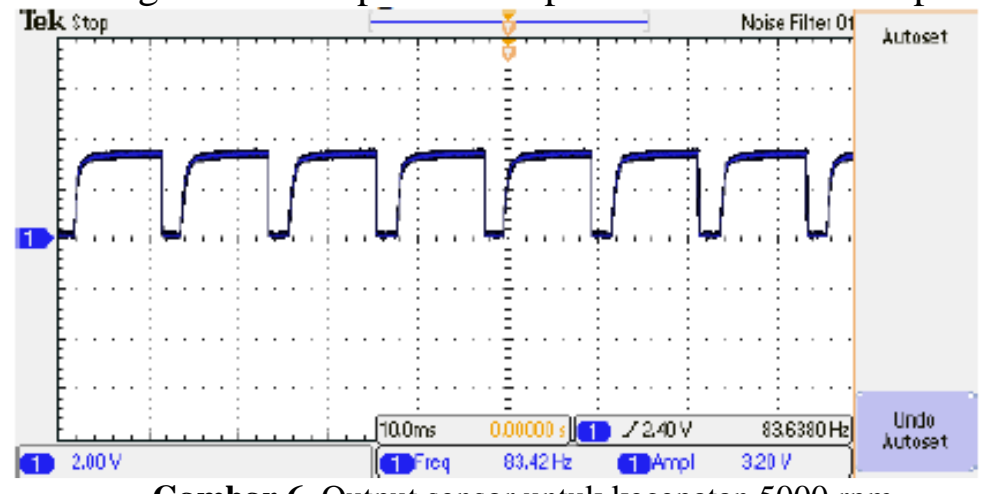

Gambar 6. Output sensor untuk kecepatan 5000 rpm

5. Hasil Pengukuran dengan Oscilocope dari Output Sensor untuk kecepatan $6000 \mathrm{rpm}$

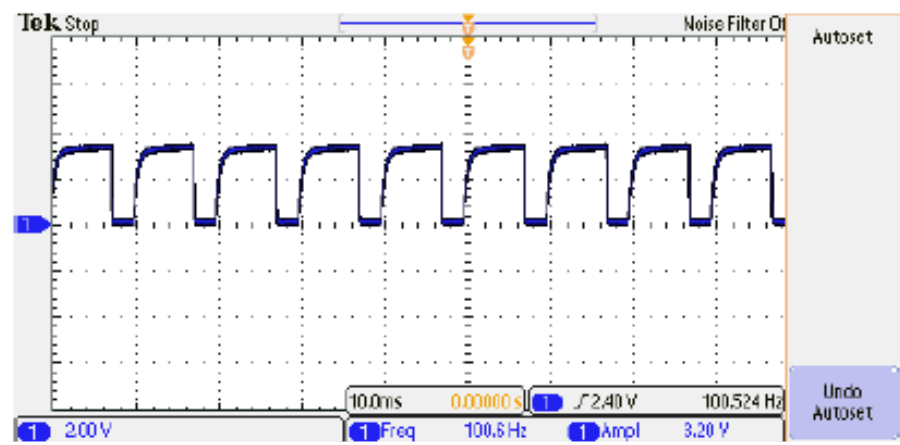

Gambar 7. Output sensor untuk kecepatan 6000 rpm

\section{Hasil Perbandingan Pengukuran antara mikrokontroler dan tachometer}

Secara umum hasil perbandingan antara pengukuran menggunanakan tachometer dan menggunakan mikrokontroller dapat dilihat pada tabel 1. berikut :

Tabel 1. Perbandingan pengukuran menggunakan tachometer dan mikrokontroler

\begin{tabular}{|c|c|c|c|c|c|c|c|}
\hline \multirow{2}{*}{ Kec } & \multirow{2}{*}{$\begin{array}{l}\text { Alat } \\
\text { Ukur }\end{array}$} & \multicolumn{6}{|c|}{ Pengukuran } \\
\hline & & 1 & 2 & 3 & 4 & 5 & 6 \\
\hline \multirow{2}{*}{500} & \multirow{2}{*}{$\begin{array}{l}\mathbf{p} \\
\mathbf{m}\end{array}$} & 535 & 525 & 511 & 512 & 513 & 515 \\
\hline & & 537 & 522 & 513 & 513 & 513 & 513 \\
\hline \multirow{2}{*}{1000} & \multirow{2}{*}{$\begin{array}{l}\mathbf{p} \\
\mathbf{m}\end{array}$} & 1025 & 1014 & 1022 & 1020 & 1018 & 1021 \\
\hline & & 1026 & 1012 & 1026 & 1020 & 1020 & 1020 \\
\hline \multirow{2}{*}{1500} & \multirow{2}{*}{$\begin{array}{l}\mathbf{p} \\
\mathbf{m}\end{array}$} & 1534 & 1525 & 1521 & 1527 & 1528 & 1526 \\
\hline & & 1536 & 1524 & 1524 & 1524 & 1524 & 1524 \\
\hline \multirow{2}{*}{2000} & \multirow{2}{*}{$\begin{array}{l}\mathbf{p} \\
\mathbf{m}\end{array}$} & 2033 & 2026 & 2019 & 2027 & 2026 & 2024 \\
\hline & & 2022 & 2022 & 2022 & 2022 & 2022 & 2022 \\
\hline \multirow{2}{*}{2500} & $\mathbf{p}$ & 2507 & 2537 & 2518 & 2527 & 2521 & 2517 \\
\hline & $\mathbf{m}$ & 2499 & 2535 & 2499 & 2535 & 2499 & 2499 \\
\hline \multirow{2}{*}{3000} & p & 3014 & 3037 & 3020 & 3018 & 3027 & 3025 \\
\hline & $\mathbf{m}$ & 3000 & 3048 & 3000 & 3000 & 3000 & 3000 \\
\hline
\end{tabular}




\begin{tabular}{|c|c|c|c|c|c|c|c|}
\hline \multirow{2}{*}{3500} & $\mathbf{p}$ & 3529 & 3531 & 3529 & 3527 & 3529 & 3530 \\
\cline { 2 - 8 } & $\mathbf{m}$ & 3528 & 3528 & 3528 & 3528 & 3528 & 3528 \\
\hline \multirow{2}{*}{$\mathbf{4 0 0 0}$} & $\mathbf{p}$ & 4028 & 4040 & 4033 & 4030 & 4032 & 4034 \\
\cline { 2 - 8 } & $\mathbf{m}$ & 3999 & 3999 & 3999 & 3999 & 3999 & 3999 \\
\hline \multirow{2}{*}{$\mathbf{4 5 0 0}$} & $\mathbf{p}$ & 4519 & 4545 & 4544 & 4535 & 4540 & 4537 \\
\cline { 2 - 8 } & $\mathbf{m}$ & 4500 & 4500 & 4500 & 4500 & 4500 & 4500 \\
\hline \multirow{2}{*}{$\mathbf{5 0 0 0}$} & $\mathbf{p}$ & 5036 & 5014 & 5024 & 5027 & 5024 & 5022 \\
\cline { 2 - 8 } & $\mathbf{m}$ & 4998 & 4998 & 4998 & 4998 & 4998 & 4998 \\
\hline \multirow{2}{*}{$\mathbf{5 5 0 0}$} & $\mathbf{p}$ & 5548 & 5536 & 5526 & 5523 & 5527 & 5533 \\
\cline { 2 - 8 } & $\mathbf{m}$ & 5454 & 5454 & 5454 & 5454 & 5454 & 5454 \\
\hline \multirow{2}{*}{$\mathbf{6 0 0 0}$} & $\mathbf{p}$ & 6010 & 6038 & 6034 & 6025 & 6027 & 6028 \\
\cline { 2 - 8 } & $\mathbf{m}$ & 6000 & 6000 & 6000 & 6000 & 6000 & 6000 \\
\hline
\end{tabular}

Keterangan $: \mathrm{p}=$ pengukuran menggunakan tachometer

$\mathrm{m}=$ hasil pengukuran menggunakan mikrokontroler

\section{HASIL DAN PEMBAHASAN}

Rangkaian keseluruhan dari sistem dapat dilihat seperti gambar 7 berikut :

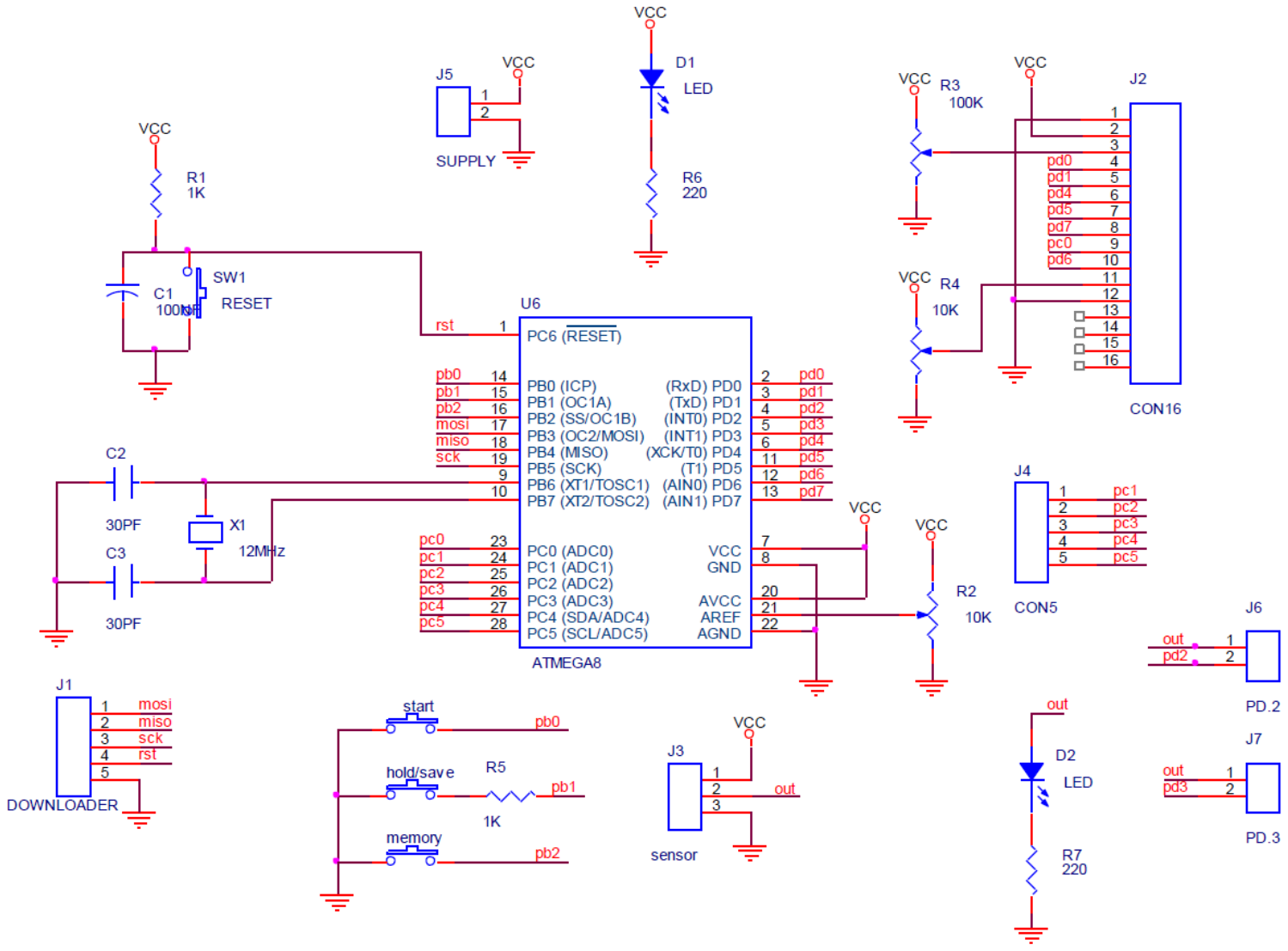

Gambar 8. Rangkaian keseluruhan sistem 


\section{Kinerja sistem secara keseluruhan}

Sensor D80NK terdiri dari rangkaian transmitter dan reciever yang bekerja pada tegangan input sebesar 5VDC. Output receiver berupa tegangan digital DC three-wire system (NPN), apabila sensor mengenai bidang reflektif maka receiver menerima logika " 0 " sehingga indikator LED pada receiver akan menyala.

Output sensor terhubung dengan PORTC.2 pada pin interupsi (INT0) ATMEGA 8. Mikrokontroler ATMega 8 bekerja dengan input tegangan sebesar 5V dengan sumber tegangan dari baterai. Indikator supply yang berupa LED akan menyala menandakan bahwa mikrokontroler telah mendapat supply tegangan.

Terdapat tiga tombol pada rangkaian diatas yang berfungsi untuk: Start, Hold/Save, dan Memory. Saat tombol Start ditekan proses pengukuran RPM akan berlangsung, sensor yang ditembakkan ke permukaan centrifuge akan mendeteksi bidang reflektif berwarna putih dengan memberikan input logika 0 (Low) pada pin interupsi (INT0) mikrokontroler dan berlogika 1 (High) apabila mengenai bidang yang berwarna hitam. Banyaknya perubahan logika 1 (High) ke logika 0 (Low) (falling edge) akan membentuk frekuensi yang akan diolah dan di ubah ke dalam satuan rotasi per menit (RPM).

Nilai kecepatan putar (rpm) generator akan ditampilkan pada LCD karakter 16x2. Setelah proses berjalan dan data yang ditampilkan mulai stabil, tekan Hold/Save. Display akan otomatis berhenti, kemudian program akan menampilkan dan menyimpan nilai dari hasil pengukuran. Tombol Memory digunakan untuk menampilkan data yang telah tersimpan pada mikrokontroler dengan maksimal penyimpanan lima data. Setelah proses pengukuran selesai dapat ditekan tombol Reset untuk memulai proses pengukuran kembali.

\section{KESIMPULAN}

Berdasarkan hasil pembahasan dan tujuan pembuatan modul dapat disimpulkan bahwa :

1. Telah dibuat Tachometer Berbasis Mikrokontroler Atmega 8 Dilengkapi Dengan Mode Hold.

2. Mode Hold dan penyimpanan data dapat bekerja sesuai yang diharapkan, dengan penyimpanan maksimal 5 data.

3. Perlu dilakukan percobaan yang lebih saat menetapkan timer periode, karena nilai timer periode berpengaruh terhadap keakurasian pengukuran rpm.

4. Semakin tinggi setting rpm yang dilakukan saat pengukuran semakin tinggi juga nilai errornya.

5. Pengukuran menggunakan metode frekuensi meter pada pin interupt mikrokontroler cukup efektif, akan tetapi karakteristik sensor yang digunakan juga berpengaruh terhadap keakurasian hasil.

\section{REFERENSI}

Badan Standarisasi Nasional. 2000. Persyaratan Umum Instalasi Listrik 2000 (PUIL2000). Jakarta

Kadir, Abdul. 2014. Buku Pintar Pemograman Arduino. Yogyakarta. Mediacom

Zurmila. 2016, "Rancang Bangun Relay Arus Lebih Berbasis Mikrokontroller Atmega 8535

". Tugas Akhir. Padang : Politeknik Negeri Padang.

Teori Generator Sinkron (2012). Diakses terakhir Januari 30, 2015. Medan : Universitas Sumatera Utara

Zuhal. 1995. Dasar Teknik Tenaga Listrik dan Elektronika Daya. Jakarta : PT Gramedia Pustaka Utama.

Wasito.S. 2001. Vademekum Elektronika. Edisi 2. Jakarta : PT Gramedia Pustaka Utama.

Refki, Diana, Permata. 2013. Pendeteksi dan Pengaman Kebocoran Gas LPGBerbasiskan Mikrokontroller AVR Atmegal6. Skripsi. Padang. Universitas Negeri Padang. 